\title{
Catholic Sociology in Ireland in Comparative Perspective
}

\author{
Brian Conway
}

Published online: 11 January 2011

(C) Springer Science+Business Media, LLC 2011

\begin{abstract}
This paper examines the relationship between the Catholic Church and Irish sociology within a comparative framework. Drawing on archival and documentary research, this linkage is investigated at an institutional and intellectual level, across three stages of the "career" of Irish Catholic sociology, and employing comparisons with Catholic sociology in France, Germany, and the United States. I discern important sources of variation between the four cases including major intellectuals, organisational hosts, and publishing outlets. Irish Catholic sociology's quite sudden movement in the direction of secular sociology in the 1950s is explained as a result of normative pressure to jettison its value-driven orientation as a result of more frequent interaction with the mainstream discipline via scholarly collaboration, the reforms of Vatican II emphasising engagement with the modern world, the demise of the broader Catholic Action movement of which it was a part, and changes in the national higher education environment.
\end{abstract}

Keywords Irish Catholicism sociology comparative Catholic Action

\section{Introduction}

This paper examines the relationship between the Catholic Church and sociology in Irish society within a comparative framework. The Catholic Church's relationship to sociology in Ireland goes back to the early 1900s when clerics began to engage with live social issues of the day. It investigates this relation at two important levels - the institutional and the intellectual. While the influence on religion-particularly Christian religion - in shaping sociology has been well charted with respect to other societies such as England and America (Baum 1989; Brewer 2007; Varacalli 1990), little attention has been paid to the Irish Catholic experience. And despite an

\footnotetext{
B. Conway $(\bowtie)$

Department of Sociology, National University of Ireland, Maynooth, Maynooth, Co. Kildare, Ireland e-mail: brian.conway@nuim.ie
} 
impressive literature on the role of the Roman Catholic Church in shaping Irish society (Corish 1970; Whyte 1984; Dillon 1993; Keogh 1995, 1996; Inglis 1998; Fuller 2002), surprisingly little has been written on the church's connection to and influence on sociology. "Catholic sociology", as it was then known - or "religious sociology" more broadly (Dobbelaere 1989, 2000)—was different to sociology as conceived today.

It was based on certain assumptions about human nature - that human beings are ethical and social beings whose everyday lives are guided by reference to supernatural forces and communal co-operative obligations and whose interests are best realised through the family and small community (Daly 1999). Moreover, it had a strong applied pastoral focus, was heavily influenced by the church's social teachings articulated in late 19th and 20th century papal encyclicals (see Table 1), and was part of a wider Catholic Action matrix of organisations and associations. It had a "negative" orientation in that it defined itself as a communitarian Catholicism against an earlier Catholic identity emphasising personal piety (Gauvreau 2005).

This article begins by placing Irish Catholic sociology in a comparative context by examining the similarities and differences between four national Catholic sociologies-French, German, U.S., and Irish. Following this, I briefly locate Catholic sociology within the wider Catholic Action movement. This is followed by an in-depth discussion of the main case study of the paper-Irish Catholic sociologybeginning with a brief description of its early furrows and central features. After this, I examine the Catholic church-sociology relationship under two headingsinstitutional structures and intellectual influences. The institutional account focuses on the establishment by the Irish Catholic hierarchy of a chair in Catholic Sociology and Catholic Action at the national seminary, St. Patrick's College, Maynooth, and whose first holder was Father Peter McKevitt. The intellectual account focuses on the published output of Irish Catholic sociologists and discerns three phases in the "career" of Irish Catholic sociology.

The fourth section of the paper attempts to account for the sudden demise of Catholic sociology in Ireland and then briefly considers the lessons learned from this case. The final section of the paper draws out the main conclusions deriving from the earlier analysis and offers some suggestions for future inquiry.

Table 1 The papal encyclicals: a descriptive summary

\begin{tabular}{|c|c|c|c|c|}
\hline Latin Title & English Title & Year & Pope & Themes \\
\hline Rerum Novarum & The Condition of Labour & 1891 & Leo XIII & Rights of Labour \\
\hline $\begin{array}{l}\text { Quadragesimo } \\
\text { Anno }\end{array}$ & After Forty Years & 1931 & Pius XI & $\begin{array}{l}\text { Right of Property; Worker Rights; State } \\
\text { Activity; Subsidiarity; Vocationalism }\end{array}$ \\
\hline
\end{tabular}

A papal encyclical refers to a letter written by the Pope and addressed to the universal church. Encyclicals can take two forms - letters addressed to the church's own internal organisation and letters taking up issues of concern for the church as a whole (Swatos 1998: 164). Some-such as the two encyclicals summarised in Table 1 - are called "social encyclicals" because they represent statements of the pope addressed to big social questions of the day. They tended to lay out abstract general principles rather than concrete social policy provisions (Daly 1999). Historically, one of the important outcomes of the encyclicals is that they provided the ideological impetus for movements within the church such as Catholic Action (Poggi 1967: 9) in resistance to the twin forces of economic liberalism and state socialism (Daly 1999) 


\section{Comparative Variation in Catholic Sociology}

As well as insufficient attention being paid to Irish Catholic sociology in the historiography of Irish Catholicism, few studies have sought to consider its comparative possibilities in relation to societal contexts such as the U.S., France and Germany. Table 2 summarises the major sources of comparative variation between these four national settings. It differentiates each national Catholic sociology along four dimensions: (1) major intellectuals; (2) organisational hosts; (3) publication outlets, and (4) the most salient national frame of reference of each.

Catholic Action was a current within the Catholic Church emphasising lay involvement. It dates back to the late 19th century but was formalised in Pope Pius XI's encyclical Quadragesimo Anno in 1931 (Vallier 1970). From the 1930s, Catholic Action spread to the Catholic countries of Western Europe but also to Latin America and North America (Vallier 1970). Catholic sociology was a subset of this wider Catholic Action movement and I focus here on Catholic sociology in the U.S., Germany and France to give the reader a sense of what was going on in Catholic sociology circles beyond Ireland at this time and the extent of cross-currents between

Table 2 Comparative variation in Catholic sociology in four countries

\begin{tabular}{|c|c|c|c|c|}
\hline $\begin{array}{l}\text { National } \\
\text { Case }\end{array}$ & Major Intellectuals & $\begin{array}{l}\text { Organisational } \\
\text { Infrastructure }\end{array}$ & Publication Outlets & Cross-Currents \\
\hline US & $\begin{array}{l}\text { Eva Ross } \\
\text { William Kerby } \\
\text { Paul Furfey } \\
\text { Raymond Murray } \\
\text { Joseph Fichter }\end{array}$ & $\begin{array}{l}\text { American Catholic } \\
\text { Sociological Society } \\
\text { National Catholic } \\
\text { Welfare Conference }\end{array}$ & $\begin{array}{l}\text { American Catholic } \\
\text { Sociological Review } \\
\text { Catholic World } \\
\text { Catholic Educational Review } \\
\text { The Ave Maria } \\
\text { Catholic Charities Review }\end{array}$ & Germany \\
\hline France & $\begin{array}{l}\text { Frédéric Le Play } \\
\text { Canon F. Boulard } \\
\text { Gabriel Le Bras }\end{array}$ & $\begin{array}{l}\text { L'Ecole de la } \\
\text { Science Sociale } \\
\text { Semaines Sociale }\end{array}$ & $\begin{array}{l}\text { Les Études Sociale } \\
\text { Lumen Vitae } \\
\text { La Réforme Sociale } \\
\text { Economie et } \\
\text { Humanisme }\end{array}$ & U.S. \\
\hline \multirow[t]{3}{*}{ Germany } & Heinrich Pesch & $\begin{array}{l}\text { Social Science } \\
\text { Research Institute, } \\
\text { University of Cologne }\end{array}$ & Stimmen der Zeit & U.S. \\
\hline & $\begin{array}{l}\text { Franz Mueller } \\
\text { Oswald von } \\
\text { Nell-Breuning }\end{array}$ & & $\begin{array}{l}\text { Die Neue Gesellschaft } \\
\text { Review of Social Economy }\end{array}$ & \\
\hline & Goetz Briefs & & Guildsman & \\
\hline Ireland & $\begin{array}{l}\text { Peter McKevitt } \\
\text { Jeremiah Newman }\end{array}$ & $\begin{array}{l}\text { Christus Rex } \\
\text { Society }\end{array}$ & $\begin{array}{l}\text { Christus Rex } \\
\text { Irish Ecclesiastical } \\
\text { Record } \\
\text { Rural Ireland }\end{array}$ & $\begin{array}{l}\text { U.S., Germany, } \\
\text { France }\end{array}$ \\
\hline
\end{tabular}


them. Irish Catholic sociologists were well acquainted with the writings of Catholic sociology in France, Germany and the U.S. as evidenced by reviews they wrote of the work of their counterparts and references made to them in their own published research and writings (Newman 1959). Non-Irish Catholic sociologists, in turn, knew of and responded to the writings of Irish Catholic sociologists (Mueller 1946).

In Germany, Catholic sociology was associated with figures such as Franz Mueller and Heinrich Pesch. Mueller received his early university education at the University of Berlin and subsequently undertook graduate study at the University of Cologne. He was centrally involved in the Königswinter study circle and some participants in this 12-member study group travelled to Rome to help with preliminary writing for the papal encyclical, Quadragesimo Anno (see Table 1). He also served as a researcher at the University of Cologne but went to St. Louis University in 1935 after losing his job at the hands of the Nazi regime. He was active in American sociology, later becoming president of the American Catholic Sociological Society (Waters 1988). A steady stream of German sociologists eventually made their way to the U.S. academy and took up appointments there as sociologists (Sullins nd).

Another central figure in German Catholic sociology circles was the Jesuit and Cologne born priest, Fr. Heinrich Pesch. Pesch's advocacy of a vocational society with a limited role for the state-neatly summed up in the term "Christian solidarism" (Ederer 1998) - found favour in Rome. Author of the massive fivevolume Lehrbuch der Nationalökonomie, he developed and promoted a specifically Catholic alternative to economic liberalism and mainstream social theory and, for this reason, Pope Pius XI sought his counsel in preparing his encyclical, Quadragesimo Anno (Ederer 1998). The influence of other German Catholic intellectuals such as Bishop of Mainz, Wilhelm von Ketteler, was important in shaping the thinking behind the earlier encyclical, Rerum Novarum (Daly 1999).

Because Catholic priests such as Fr. William Kerby, Fr. Frederick Seidenberg, and Fr. Peter Dietz trained in German universities and later emigrated, they brought Catholic sociology with them to American universities such as St. Louis University, Georgetown University, and the Catholic University of America, and, as a result, there were frequent cross-currents between German Catholic sociology and American Catholic sociology. Unlike in Germany, Irish Catholic sociology lacked a central intellectual figure of Mueller and Peisch's standing and was not a major international training ground for Catholic sociologists. Neither did Irish Catholic sociologists make significant contributions to methodological debates compared to French Catholic sociologists such as Frédéric Le Play.

In France, Catholic sociology was prominent in the L'Ecole de la Science Sociale and the Catholic Institute of Paris and French Catholic sociologists tended to rally against Durkheim for his insistence on the social origins of religion. Influential Catholic sociologists included Canon Fernand Boulard, Henri de Tourville, Paul Descamps and M. Pinard but most notably Frédéric Le Play, founder of the Société Internationale des Études Pratiques d'Economie Sociale in 1856 and of La Réforme sociale, the publishing outlet of this society (Hill 1999a). A plethora of organisations existed in France-Le Centre Catholique de Sociologie Religieuse, Economie et Humanisme, Le Centre Pastoral des Missions à l'Intérieur, and Action Populaireand all promoting Catholic sociology (Delacroix 1952; Hervieu-Léger 1990; Jackson 1959; Boulard 1960; Marjolin 1937; Périer 2002; Ross 1950). 
Against Comtean sociology, Le Play and his followers emphasised the social reform possibilities of sociology rather than the abstract understanding of society associated with a more positivistic conception of the discipline linked to Comte. He also made an important methodological contribution, noting the importance of direct observation as a fieldwork data gathering tool (Hill 1999a).

Another central figure in French Catholic sociology was Gabriel Le Bras. Le Bras served as director of the Section religieuse de l'École des Hautes Études and produced an impressive body of religious sociology writings. He also taught the subject at the Institut des Études politiques (Delacroix 1952). Catholic sociologists such as Le Bras urged the practice of historical research grounded in the use of archives, studies of religious behaviour using census or social survey data, as well as research relating to the clergy such as trends in church personnel, seminary formation, and the social background of priests. This led to research on such things as Mass attendance by parish and resulted in a spatial classification of religious practice (Jackson 1959; Vogt 1955). Taken together, French Catholic sociologists carried out an impressive range of empirical, historical and pastoral research relating to French Catholicism.

Catholic Sociology in the U.S. shared many of the concerns of earlier "Christian Sociology"- sometimes referred to under the rubric of "Social Gospel"-including an ambition to make sociology relevant to religious goals of social improvement (Reed 1981, 1982). The high water mark of Christian sociology were the early decades of the 20th century but it went into decline by the 1920s and American sociology found little room for Christian writings until the emergence of Catholic sociology in the 1940s (Reed 1981, 1982).

American Catholic sociology was associated in the 1940-70 time period with priest sociologists such as Fr. Paul Furfey, Fr. William Kerby, Fr. Raymond Murray and lay people such as Eva J. Ross (Hill 1999b; Sharkey 2005; Cavendish 2007) and found organisational expression in the American Catholic Sociological Society. Institutionally, it was heavily linked to Catholic universities such as St. Louis University, St. Thomas College (Georgetown University), University of Notre Dame, Fordham University, and Catholic University of America (Nuesse 1998; Blasi and Donahoe 2002; Cavendish 2007). American Catholic sociologists tended to distance themselves from the secular discipline because of its positivistic orientations and its eschewing of the importance of social rights such as the right to property, justice and life. In short, it tended to rally against the ethics-free nature of secular sociology (Cavendish 2007). American Catholic sociologists struggled, however, with making their vision of the discipline appeal to general audiences beyond a Catholic confessional one and some among their number sought to straddle these two publics. The name change of the journal American Catholic Sociological Review to Sociological Analysis in 1963-64 signalled increasing dissatisfaction with the turn to Catholic social ethics as a guide for sociological research and its displacement by empirically grounded theory (Facey 1964; Ross 1940).

In each country, Catholic sociology shared an emphasis on making sociology relevant and pertinent to the social world and on marshalling Catholic religious values and beliefs in realising this. Secondly, in each context similar discursive and organisational strategies in the form of such things as study circles, public lectures, summer schools, confessional periodicals, and co-operative movements (Brewer 2007; Gauvreau 2005; Kivisto 1989; Varacalli 1990; Fichter 1973; Rawe 1940; 
Waldron 1950) were adopted to promote and disseminate this new way of "doing" sociology. What remains puzzling about the specifically Irish experience is how sudden and dramatic the turn to secular sociology - and away from the earlier Catholic sociology phase-was in the 1950s.

This paper attempts to unpack this puzzle. Almost all of the research of the small number of priest sociologists who worked in Irish universities in the 1930s through to the 1950s, consisted of articles in confessional periodicals (Beckford 1990) such as Rural Ireland, Christus Rex, The Furrow, Studies, and the Irish Ecclesiastical Record. This early output of Catholic sociologists-spanning the time period extending from the 1930 s through to the 1950 s - was focused on disseminating or "domesticating" the ideas contained in the papal encyclicals to an Irish audience and in a largely uncritical light. A second phase emerged in the $1950 \mathrm{~s}$ in which an attempt was made to bring empirical data to bear on theological reflections about the social world. The jettisoning of Catholic sociology in the late 1950s represents the third phase of its career and its replacement by a scientific approach to the study of social life.

To help set the context for the more detailed discussion of the intellectual and institutional dimensions of Irish Catholic sociology that follows, I first situate it within the broader Catholic Action movement that emerged in continental Western Europe in the late 19th and early 20th century and the relationship of Catholicism to sociology, and particularly, to Marxism.

\section{The Catholic Action Matrix}

Catholic sociology in Ireland was part of a wider Catholic Action matrix. Catholic Action was a burgeoning movement in continental Europe at the end of the 19th century and spread to other parts of the Catholic world including North America (Gauvreau 2005; L'Estrange 2007). Pope Pius XI defined Catholic Action as having to do with the participation of the laity in the Church's apostolate (Newman 1958b) and as a result it became an umbrella term for a wide range of organisations of lay activism, prefiguring the emphasis on the laity in the "People of God" formulation of Vatican II. Its key goal was the creation of a Christian, or more specifically, a Catholic social order that would bridge the church, on the onehand, and the world on the other (Poggi 1967). It attached central importance to the civic participation of the Catholic laity in such things as trade unions, occupational guilds, rural societies and other co-operative Catholic organisations outside of the structures of the state. This co-operative focus sat uneasily with a strong state and because of this a strong antistate bias ran through the Catholic Action project. Importantly, Catholic Action was conceived of as a mass movement that would transform social organisation and state activity in accordance with church teaching. Along the way, it would not shy away from discursively challenging external social groups resistant to this project (Keogh 1996) but the movement also frequently involved internal collisions between activist lay people and traditionalist Catholic clergy over the meaning and scope of lay involvement (Gauvreau 2005).

This sometimes fraught relationship between lay and clerical opinion over the direction of Catholic Action extended to Rome's relationship to "religious 
sociology". Karel Dobbeleare's historical account (Dobbelaere 1989) of the origins and development of the International Conference for the Sociology of Religion/ Conférence Internationale de Sociologie Religieuse (ICSR/CISR), for example, reports that the organisation began as a non-confessional entity in 1948, then became confessional in the early 1950 s by merging with theology, but owing to different and colliding outlooks of the discipline among clerical and lay members as well as dissatisfaction from Rome with it being anything other than a research organisation representing confessional interests, it parted company with its confessional past in 1969 (Dobbelaere 1989). This marked an important turning point in the sociological study of religion-religion shifted from being the repository of values guiding sociological investigation to becoming an object of sociological inquiry in itself via attention to patterns in belief and practice and the importance of religion in shaping people's everyday lives. Put another way, "sociology of religion" superceeded "religious sociology" and paved the way for the emergence of a sociology of Catholicism (Dobbelaere 1989; Facey 1964; Swatos 1989; Sullins nd).

In the Irish case, Catholic action took the form of a rich variety of inter-connected organisations and societies such as An Rioghacht, the Knights of Columbanus, Saint Vincent de Paul, Muintir na Tíre, the Legion of Mary, the Christus Rex Society, and the Catholic Young Men's Societies as well as entities such as the Dublin Institute of Catholic Sociology, all of which were engaged in promoting lay participation in the church though with varying degrees of success ${ }^{1}$ (Hartigan 1992; O'Driscoll 1994; O'Leary 2000; Kelly 1999). As in other Catholic countries, these organisations tended to cut across class lines - some catering to the interests of farmers - such as Muintir na Tíre, for example — while others - such as the Dublin Institute of Catholic Sociology - responded to the needs of the working-classes particularly in the area of adult education. Still others - such as the Catholic Young Men's Societiesresponded to the needs of distinct groups defined by gender and age.

Intellectually, Catholic Action was of continental European origins and responded to the political conditions prevailing there and particularly to fascism, socialism and communism. Catholic countries like Belgium, Spain, and Italy all had strong communist and left-wing movements ideologically opposed to Catholicism. But because of the global character of Catholicism, Catholic Action was applied within the universal church even though its ideological 'others' were much less influential or only marginally present in some non-continental western European societies such as Ireland (Fahey 1998).

Sociology, of course, played an important role in the history of communist thinking. Karl Marx's writings, for example, were the wellspring from which communist-inspired social movements drew their intellectual motivations and political strategies. Not surprisingly, his writings were also the subject of criticism by early Catholic sociologists who bemoaned communism's attempt to purge the social influence of religion and to usher in a non-religious society. This kind of

\footnotetext{
${ }^{1}$ The relationship of these various organisational entities to episcopal authority varied from diocese to diocese. Their presence in a diocese was not always seen as a godsend by the local bishop and as a result some bishops were less approving of them than others and sought to bring them under their direct diocesan control (Curtis 2010) despite the fact that each had a simple organisational structure involving pastoral work through the local parish. On the relationship of Catholic Action to clerical authority in the U.S. context see O'Brien 1971 and in relation to Italy see Poggi 1967.
} 
sociology promoted a view of human beings as ethical-free and driven by materialistic forces and conditions. In their own writings, Catholic sociologists sought to subject Marxist ideology to critical analysis and to displace it with the social teachings of the church, with the aim of building up a Christian social order. This represented a dogmatic approach to the understanding of social life by insisting on Catholic theology and ethics as the basis for organising and constructing a viable social and economic model. In the Irish example, the very title of Peter McKevitt's book, The Plan of Society (McKevitt 1944), communicated this well (L'Estrange 2007).

By the 1950s, though, Catholic sociologists themselves were becoming more convinced of the value of empirical data gathering and of confronting theological reflection contained in the church's encyclicals with 'on the ground' research (Newman 1957). Instead of ideologically resisting secularisation and showing allegiance to the truth claims of the church's social teaching, they sought more and more to carry out research identifying the tendencies, patterns and regularities in the extent to which society was experiencing a decline of religious identity. Jeremiah Newman, for example, felt that change was on the way, writing in the late 1950s, that "it may well be that very shortly we will find a general change over to what has been Irish usage of the term 'Sociology' for many years... One of the first tasks to be tackled by Irish Sociology in the future is the building up of a fund of factual information about the various domains of social life' (Newman 1957, p. 75). In the pages of Christus Rex, American contributors such as Ralph Lane of Fordham University acquainted his mainly Irish clerical readership with trends in American Catholic sociology and urged Irish Catholic sociologists to make more extensive use of empirical research especially at the parish level (Lane 1954). Through this change in orientation, Irish Catholic sociology achieved a rapproachement with mainstream secular sociology that it lacked in its earlier beginnings. Increasingly, as we will see, Catholic sociologists wrote positively about the potential of sociology to contribute to the understanding of the big social issues of the day.

\section{Irish Catholic Sociology: Institutional Structures}

Catholic sociology was a form of religious sociology (as distinct from a sociology of religion) and, as mentioned earlier, exhibited the major features of this enterprise identified by Robin Gill including a pragmatic or practical orientation, a reliance on theology, and a rejection of value neutrality (Gill 1974). To realise this project, the Catholic Church in Ireland did a number of things. First, it established a chair in Catholic Sociology and Catholic Action at St. Patrick's College, Maynooth, with endowment support from the Knights of Columbanus. Although the Knights put forward the funding it took some time before the chair was filled, and there was a 7-year lag from the initial proposal to establish the chair by the Catholic hierarchy in 1930 to the filling of the chair in $1937^{2}$ (Bolster 1979; Corish 1995). McKevitt was appointed on 12 October, 1937 (Maynooth College Calendar 1937: 292). Such was the importance of the appointment, that it was noted in the Irish Catholic

\footnotetext{
${ }^{2}$ For a detailed account of the endowment of the Maynooth chair in Catholic Action and Catholic Sociology see Bolster 1979:61-63.
} 
Directory's record of Irish ecclesiastical events for 1938 (Irish Catholic Directory, 1939, pp. 643-644). Significantly, the chair was located in the university's theology faculty. ${ }^{3}$

McKevitt was not a trained sociologist. He held undergraduate degrees in divinity and canon law from Maynooth as well as the doctor of philosophy degree from the Catholic University of Leuven, Belgium. This was a preferred training ground for Catholic sociologists as U.S. Catholic sociologists such as Fr. William Kerby also received postgraduate training in Leuven (Blasi and Donahoe 2002). McKevitt's 1938 doctorate was awarded by the Belgian university's Institut supérieur de philosophie, and focused on the writings of philosopher R.S. PringlePattison (1856-1931). ${ }^{4}$

In preparation for this teaching responsibilities in Maynooth, McKevitt went to Rome in 1938 where he studied sociology, international labour organisation, political economy and the social encyclicals at the Angelico, Catholic Action at the South American College, and the history of Russian Bolshevism at the Russicum. ${ }^{5}$

On his return to Maynooth, McKevitt threw himself into the activities of the Christus Rex Society as well as teaching the social encyclicals of the church to students ${ }^{6}$ preparing to become priests. After McKevitt's retirement from the chair, priest sociologist Jeremiah Newman took up the position. He, in turn, was succeeded by another priest sociologist, Liam Ryan.

A second important institutional development that helped to establish Irish Catholic Sociology was the founding of a society of priests - the Christus Rex Society - to promote the social teachings of the church. This society organised such things as annual meetings, diocesan groups, annual congresses, and, significantly, published its own periodical, ${ }^{7}$ Christus Rex (Daly 1967). Although a dedicated clerical organisation, the Christus Rex Society did consider the possibility of opening itself to lay membership but never committed itself one way or another (McKevitt 1955a). Between the covers of the periodical, clerics wrote about social life and social problems in Ireland. Priests who contributed articles to it - or to other denominational periodicals - included Peter Coffey, Cahal Daly, Cornelius Lucey, Edward Cahill, and Michael Cronin. Its publication spanned over two decades, from 1947 to 1971, and during this time the journal celebrated small-scale rural cooperative living and bemoaned industrialisation, urbanisation, and state intervention (Peillon 1982).

\footnotetext{
${ }^{3}$ A committee comprising Bishop Browne of Galway, Bishop Kinane of Waterford and Lismore, Cornelius Lucey, and the university president and vice-president, recommended that sociology be taught under the rubric of the theology faculty (Corish 1995:315).

${ }^{4}$ Library catalogue, Catholic University of Leuven, Belgium.

${ }^{5}$ This information comes from the President's report, St. Patrick's College, Maynooth archive.

${ }^{6}$ Among McKevitt's students was Father Patrick Purcell. Fr. Purcell was active in Muintir na Tíre, serving as honorary recording secretary in the 1960 s and he travelled the country giving lectures to guilds of the organisation (Rural Ireland 1964:60).

7 This society, founded in 1941, sought to build a Gospel inspired social order in Ireland. It encouraged priests throughout Ireland to join it and contribute to its work of creating a Catholic Ireland. Proceedings of the society's annual congress were often reported in periodicals such as The Furrow (Mullan 1960: 403-407) at which clerical and lay people spoke.
} 
As holder of the chair in Maynooth, Peter McKevitt was active in the organisation. In 1947, he and Cornelius Lucey ${ }^{8}$ made up the central executive committee of the Christus Rex Society and, with Cahal Daly, acted as editor of Christus Rex (Daly 1967; ICDA ${ }^{9}$ 1947). Indeed, McKevitt could claim some credit for the founding of the organisation because as part of his teaching role, McKevitt helped establish a Sociology Club at Maynooth for senior seminarians at which Catholic sociology texts like Edward Cahill's The Framework of a Christian State (Cahill 1932) and Michael Cronin's Primer of the Principles of Social Science (Cronin 1927) were the subject of study and discussion (Meehan 1982; L'Estrange 2007).

The inaugural issue of Christus Rex included an article by McKevitt on "The Study Circle"- analogous to the semaines sociales in places like Quebec (Barnes 1961; Gauvreau 2005), in which he proposed the study circle as a space for the discussion of the church's social teachings. He saw study circles as small-scale schools of Christian citizenship: "our object is to arouse interest in social problems and remedies and give guidance in good citizenship. By this method the members grow sharper in observation and acquire the habit of constructive criticism. They learn to look for the principles which should govern the conduct of industrial and civic life. Is not this an urgent need in any community?" (McKevitt 1947:39). McKevitt went on to give a "how to" guide in the running of the circles and to this end gave suggestions for readings and maintaining student interest (McKevitt 1947).

\section{Irish Catholic Sociology: Intellectual Structures}

Apart from establishing sociology institutionally in Ireland, the Catholic church's influence on sociology also operated at an intellectual level. In what they wrote about and said, Irish Catholic sociologists promoted a concern with making sociology useful to society and engaged in particular with issues to do with rural life, religion, education and the family. As mentioned earlier, three phases can be discerned in the history of Irish Catholic sociology. The first phase involved applying the social teachings of the church to the Irish situation and in so doing seeking to bring about social reform. One good example of this was Peter McKevitt's The Plan of Society. ${ }^{10}$ Published in 1944 by the Catholic Truth Society of Ireland, this almost 220-page book, the first sociology textbook in Ireland,

\footnotetext{
${ }^{8}$ From 1929 to 1950 , Cornelius Lucey was chair of philosophy and political theory at St. Patrick's College, Maynooth. In 1950 he became professor of logic, metaphysics and ethics (Irish Catholic Directory and Almanac 1950:690). His academic credentials were impressive: first class honours degree in English language and literature (1923), Licentiate in Theology (1929), Doctorate in Theology (1929), M. A. in philosophy with first class honours (1930), and the D.Ph. from the University of Innsbruck (193132) (Irish Catholic Directory and Almanac 1951:769). Lucey served as editor of Christus Rex and during the 1930s and 1940s was a regular contributor of articles to the Irish Ecclesiastical Record on a broad range of topics including education, social security, and Catholic social teaching. He was also co-founder of the Christus Rex Society in 1941 (Canning 1987:255) and served as President and member of the National Executive Committee of Muintir na Tíre in the 1960s (Canning 1987:255).

${ }^{9}$ Irish Catholic Directory and Almanac. This title (1870-1959) was changed to the Irish Catholic Directory in 1960.

${ }^{10}$ This account of Father Peter McKevitt draws heavily on a forthcoming brief biographical article in Sociological Origins (Conway forthcoming).
} 
contained a foreword in which McKevitt addressed the book to clerical students of Catholic sociology in Maynooth as well as audiences beyond Maynooth. Aware of the limits of a work of synthesis, he urged readers to work 'off the page' by doing their own readings from the bibliography supplied at the end. The book's chapter titles (McKevitt 1944: xiii-xv) are set forth in Table 3 below and give one a sense of the kind of topics Irish Catholic sociologists engaged with in their work.

Though McKevitt saw his book as a work of sociology, he argued that the sociological standpoint only went so far and a full understanding of society called for the integration of the insights of this "partial science" (McKevitt 1944: ix) with the lessons of the papal encyclicals.

Admittedly, the monograph lacks an accumulative ambition-each chapter more or less stands alone rather than each adding to or building towards an overarching argument. An American reviewer likened it to similar European Catholic sociology texts (Mueller 1946). This is not surprising, perhaps, given that McKevitt had read the writings, in particular of French Catholic sociologists, and the bibliography of the book cites the work of the French semaine sociale. He also cited the work of Heinrich Pesch in the book's introduction. McKevitt devoted the short postscript of The Plan of Society to the lengthy 1944 report of the commission on vocational organisation, a government appointed commission established to consider the redistribution of power in Irish society. He noted its import for 'our whole institutional life' (McKevitt 1944: 197) and sought to assess it against the benchmark of Catholic social teaching. Like other Catholic intellectuals, McKevitt welcomed the report's call for bottom-up local power structures vested in vocational organisations as a corrective to centralised state power or the "danger of bureaucratic encroachment on personal liberty”, as McKevitt put it (McKevitt 1944: 198).

Table 3 The contents of Peter McKevitts' The plan of society
1. "The Individual Person"
2. "The Family"
3. "The Problem of Population"
4. "Distribution of Population"
5. "Man's Livelihood-Property"
6. "The Worker's Share"
7. "Industrial Organisation"
8. "The Unemployment Problem"
9. "Political Organisation"
10. "The Church and Racism"
11. "Spiritual Factors of Unity"
12. "Purpose and Competence of the State"
13. "Church and State"
14. "Church and State: Further Determinations"
15. "The Liberal Conception of the State"
16. "Marxian Socialism"
17. "Cooperative Organisation"
18. "World in Transition" 
Although McKevitt wrote articles in Catholic sociology outlets such as Christus Rex (McKevitt 1955c), he also wrote occasionally in explicitly theological periodicals such as the Irish Ecclesiastical Record. For instance, he wrote homilies (McKevitt 1962) and articles on topics such as Jewish identity (McKevitt 1935), communism (McKevitt 1965), the Irish labour movement (McKevitt 1941), the living wage (McKevitt 1940), and British social policy (McKevitt 1943), in this periodical in the 1930s, 40s and 60s. He also wrote some book reviews for The Furrow (McKevitt 1967), articles on Christian vocational society (McKevitt 1956a) and leisure (McKevitt 1955b) in Rural Ireland (McKevitt 1956a), and book chapters in edited volumes (McKevitt 1970).

A concern with "public sociology" was evident in McKevitt's writings on social policy such as the Beveridge Plan (1942), a post-war social reconstruction programme for Britain, and the living wage. Although McKevitt approved of much of the Beveridge plan in general terms, he was less convinced that a British society emerging from the war could back up its promised social welfare commitments with adequate funding (McKevitt 1943:148-149). About transposing the Beveridge Plan to the Irish situation he was clear in his assessment: "The Beveridge Plan for Social Security is not for export" (McKevitt 1943:150). Turning to the concept of the living wage promoted by Pope Leo XIII, McKevitt prefaced his remarks on it by saying that the moral compass provided by papal encyclicals "must be utilized to shape our institutions and to test their soundness" (McKevitt 1940:143). He went on to make an argument for the living wage, describing it as necessary for a "decent human livelihood" (McKevitt 1940:145) and for the "dignity and support of the family" (McKevitt 1940:146).

Another area of interest where he sought to promote a more engaged sociology related to rural living. In an article in Christus Rex he took up the issue of rural decline and particularly the outmigration of young people from rural areas (McKevitt 1952a:55). McKevitt worried about the impact of urbanisation, and the technological developments associated with it including the advent of transportation and new media such as the radio, on the quality of rural living and particularly the ability of young people to find suitable marriage partners (McKevitt 1952a:56). Wary of promoting a rosy view of rural living, at the same time, he urged intervention - by co-operative organisations such as Muintir na Tíre working through the local parish structure - to stabilize rural communities.

Not surprisingly, and owing something to Catholic sociology's social reform orientations, bringing sociology to the attention of different publics was also a key concern of McKevitt. He was a regular speaker at Muintir na Tíre gatherings and Christus Rex Society congresses and commented upon important public reports such as the Report of the Vocational Commission (ICDA 1945:709) and the Farmers' Commission report (McKevitt 1956b; Cork University Record 1949: 13).

McKevitt's successor, Jeremiah Newman, took Catholic sociology in a new direction by beginning to confront its theological assertions with empirical data. This involved an engagement with secular sociology rather than a corralling of Catholic sociology from it, as occurred in relation to religious sociology in England (Brewer 2007). A second new direction of Catholic sociology during this phase in its "career" involved the use of empirical data to aid in the church's pastoral planning and development, reflected, for example, in the collection of data about motivations for and trends in Catholic vocations (Newman 1962, 1966, 1968), a practice that also developed in the U.S. context (Fichter 1966, 1973). 
Foreshadowing this second phase in a book note in Christus Rex in 1952, McKevitt acknowledged the value of methodological pluralism - he recognised the use of the social survey in gauging "the strength and extent of any observable activity" while also appreciating interpretative approaches that alert us to the fact that "conduct externally identical may have varying significance for the agents" (McKeviitt 1952b: 469). In his 1947 Christus Rex article on study circles, he applied this perspective by emphasising the importance of direct empirical observation of the lives of workers allied with the use of statistical data-from such sources as the local Labour Exchange - in understanding their everyday lives (McKevitt 1947:36). At the same time, McKevitt rallied against the discipline for its positivistic orientations, writing in 1944 that, "it looks as if Catholics have an important role to play in delivering the science from the prejudices of those whose positivist outlook prevents their taking a comprehensive view of social development" (McKevitt 1944:ix).

Jeremiah Newman trained for the priesthood at Maynooth and was ordained in 1950. Two years after ordination he undertook further postgraduate work abroad at the Catholic University of Leuven where he was awarded the doctor of philosophy degree in 1951 for a dissertation, based on his earlier M.A. thesis under the supervision of Cornelius Lucey, on the ideas on legal justice of the medieval saint, St. Thomas. This was published 3 years later in book form and carried the imprimatur of the then Catholic Bishop of Cork, Cornelius Lucey (Newman 1954).

His first academic appointment was as lecturer in the Queen's University Belfast, a post he held for a short period from 1952 to 1953 (Irish Catholic Directory 1975; Canning 1987). He was then appointed professor of sociology in St. Patrick's College, Maynooth, serving from 1953 to 1968, when he was appointed President of the college (Christus Rex 1970). The fact that the earlier 'Catholic Sociology and Catholic Action' professorial title of McKevitt was dropped was of symbolic significance-it signaled the beginning of a movement away from explicit identification with the Catholic sociology tradition.

Between 1954 and 1983 Newman published 19 books or book-length monographs, nearly all by Irish publishing houses like Talbot Press, Cork University Press, and Gill \& Co., Dublin. He wrote an introductory sociology textbook, conducted a pioneering Limerick Rural Survey, and began a new research enterprise involving the collection of empirical data to help the church better understand trends in vocations and religious belief and practice. Beyond sociology, Newman was also deeply interested in philosophy, especially continental European philosophy in the writings of Merleau-Ponty and Lefebvre. ${ }^{11}$ Through his involvement in organizations such as the European Society for Rural Sociology (Newman 1967) and the European Study Group on Organising Resources for Community Development ${ }^{12}$ and through international research collaborative linkages with American sociologists at universities in Chicago and St. Louis and Dutch sociologists in Wageningen,

\footnotetext{
${ }^{11}$ Newman offered a defence of Christianity against Marxism and other social philosophies (Newman 1951: 14-25).

12 The European Study Group on Organising Resources for Community Development met in Gormanstown, 30 June-7 July, 1962. Newman helped establish this group and served as its director. Its meeting in Gormanstown was attended by the then Archbishop of Cashel and Emly, Dr Thomas Morris, the then President Eamonn DeValera, and the then Taoiseach, Sean Lemass (Irish Jesuit Archive, Box 4, File 4, Social Survey (1966-68)).
} 
Newman brought Catholic sociology into dialogue with the mainstream-and increasingly internationalised and professionalised-discipline elsewhere (Ward 1964). Such was Newman's engagement with the discipline beyond Ireland that other Catholic sociologists cited him in their work (Varacalli 1990).

Newman's early works represented a bridge with McKevitt's concerns and interests. His 1955 text Co-Responsibility in Industry (Newman 1955), for example, was an analysis of industrial relations from a Catholic social action perspective with a strong emphasis on balancing concerns about efficiency with due regard for equity on the factory floor. A sympathetic reviewer in Christus Rex described it as a "book which deserves to be read from cover to cover by every industrialist, labour leader and politician who has the true interests of Irish industrial life at heart" (McCaffery 1956:295). A second related book, What is Catholic Action?, was praised by J.C. McGarry, professor of pastoral theology at Maynooth, as a "timely introductory study of the lay apostolate" (McGarry 1958:620).

More than McKevitt though, Newman sought to bring sociology into dialogue with theology - by contrast, McKevitt felt that only theology could be brought to bear on sociology - and his writings during the following decade of the 1960s reflected this. Consider, for example, his text examining the paradox of change and continuity in the Catholic Church (Newman 1965). In this work, Newman noted the uneasy historical relations between theology and sociology, claiming that sociology's sometimes anti-Christian orientation helped explain why theologians "could be forgiven for believing that little illumination was to be had from that quarter" (Newman 1965:28), but insisted on sociology's contribution to helping the church better understand itself.

Like McKevitt, Newman also wrote an introductory sociology textbook but it bore little resemblance to McKevitt's earlier The Plan of Society. Instead of laying out Catholic social principles for an Irish audience, Newman engaged much more with the sociological literature on different theoretical traditions from Durkheimian sociology to Weber's historical sociology than his predecessor $\mathrm{did}^{13}$ and offered a full mapping of the disciplinary subfields of family, culture, politics, urban, rural and the sociology of education (Newman 1972). The book's preface reminded readers that it was "the written version of courses of lectures in Sociology" the author gave at St. Patrick's College, Maynooth, University College Dublin, and the Institute of Public Administration (Newman 1972: vii). He also made much more extensive use of footnotes, citing the sociological literature, than McKevitt and was well acquainted with the work of sociologists such as Robert Merton, Lewis Coser, David Riesman, Thorsten Veblen, Joseph Fichter, Basil Bernstein, and Karl Mannheim.

Catholic sociology's concern with making sociology useful to the church's pastoral planning was reflected in Newman's rural sociology studies (Newman 1958c, 1958d, 1964). Understanding rural communities better was motivated by concerns about emigration but also reflected a realization of rural communities as well-springs of Catholic vocations. Newman's Limerick Rural Survey, sponsored by Muintir na Tíre and grant aided by the Counterpart Fund (Newman 1964; Murray and Feeney 2010; Ward 1960:437), was a landmark study of Irish rural life.

\footnotetext{
${ }^{13}$ Although notably different in content and approach to McKevitt's work, Newman cited The Plan of Society in a chapter dealing with culture and society in his own textbook (Newman 1970:129).
} 
Although Patrick McNabb carried out the empirical component of the study and wrote two major parts of it, Newman wrote the report's 59-page account of social provision in the countryside, making a strong case for strong rural towns to counteract outmigration to urban areas. Newman remarked that a noteworthy feature of it was that it "used human geography and history to an unusual degree in a way that may be hoped to have shown their value for rural sociology" (Newman 1967:68). The basic finding of the Limerick Rural Survey was that rural Ireland was undergoing change and specifically that farmers were increasingly taking urban dwellers as their reference group and, as a consequence, developing new expectations about such things as working conditions and wages that made it difficult to sustain a viable rural livelihood (Newman 1967:66-67).

Harnessing Catholic sociology for improving the church's pastoral strategies was also reflected in Newman's interest in the sociology of religion. Much of his work in this area was carried out to inform church planning in relation to recruitment and promotion of vocations. In a review of the papers presented at the Fifth International Conference on Religious Sociology, held in Louvain, Belgium in 1956, Newman argued there was a need for sociologists to study the sociology of religion: "whether we call it Sociology of Religion, Sociology of Vocations, Sociology of the Parish or Rural Sociology - the name does not matter-we in Ireland must study these questions more and more" (Newman 1959:417). He went on to warn about the consequences for the church of rural decline: "let us lose our rural population just a little more and we may be confronted with a shortage of vocations on the home front, to say nothing of a falling off in our missionary work" (Newman 1959: 417).

In another venue he was even more emphatic about the value of the sociological perspective in helping to understand religion, writing in a 1953 Christus Rex article reviewing the literature in "religious sociology", that clergy privileged doctrinal perspectives on religion over sociological ones, and urging them to give due regard to the sociological perspective: "we would do well to give it more attention. We are so preoccupied with what religion ought to be that we are frequently blind to what it is. We concentrate on telling the faithful what they ought to be doing without observing what in fact they do, or what precisely are the conditions which would permit our teaching to make better and more effective contact with life" (Newman 1953:589-590).

An understanding of the sociological forces influencing Catholic vocations ${ }^{14}$ led him to write an article in The Furrow in which he isolated the healthy state of the church, strong Catholic families, the education system, and the respect enjoyed by priests in Ireland as important considerations. But he sounded a note of caution by pointing to social change, especially urbanisation, that might give rise to disquiet

\footnotetext{
${ }^{14}$ Newman returned again and again to the topic of vocations. A lecture he gave at the First International Conference on Priestly Vocations in Europe in Vienna, 1-12 October 1958, was published in the Maynooth periodical The Furrow in 1958 (Newman 1958a), and in it Newman recalled his visit to the Vocation Institute at the University of Notre Dame, Indiana, where he attended a seminar on the sociology of vocations at which Joseph Fichter, a respected Jesuit sociologist of religion, presented a paper. Fichter argued that Catholic high schools were important sites in helping to foster vocations (Fichter 1966). Newman agreed and likened the Catholic high school in the American context to Ireland's diocesan secondary (often boarding) schools, which tended to operate as feeder schools for the major seminary at Maynooth. Even at this time, at the end of the 1950s, Newman was optimistic about Ireland being able to keep up the supply of priests for duties at home and abroad.
} 
about vocations in the future. Overall, his assessment of the Irish situation was upbeat: "Ireland is still a country that is rich in vocations and one that sends hundreds of priests yearly to other areas" (Newman 1958a:716). A more empirical, quantitative article was written for the Irish Ecclesiastical Record in 1962 detailing trends and patterns in missionary vocations for the church's growing 'spiritual empire' and Newman reminded the reader that "it should not be forgotten that the interests of the survey are sociological in so far as it is concerned with factual realities of the Irish Church in our day relating to needs and possibilities in the domain of clerical personnel" (Newman 1962:1). But he had reservations about the sociological survey too, and made the case that "sociological analyses are instruments at the service of the Church. Properly used they can be of immense practical value. But they are unable to provide complete explanations of human phenomena and they take no account of the mysterious workings of the grace of God" (Newman 1962:2)

Newman's successor in 1969-priest sociologist, Liam Ryan-continued Newman's efforts to make sociology socially useful by bringing it to bear on the church's pastoral planning and by engaging with live social problems of the day. His Social Dynamite work (Ryan 1967), an interview-based study of the career and educational aspirations of early school-leavers living in a local authority housing estate in "Parkland" (a pseudo name for a troubled housing estate in an unidentified city in Ireland) and drawing on W.I. Thomas's concept of the "definition of the situation", as well as his doctoral dissertation research on the assimilation experiences of Irish immigrants in London (Ryan 1973), both represented examples of bringing empirical "facts" to bear on sociological theorising, and a movement away from the earlier heavily normative focus of Catholic sociology. Ryan also carried out research in relation to patterns and trends in religious belief and practice (Research and Development Unit 1971; Ryan nd), continuing the tradition of Newman's earlier vocations research in the service of the church. Other research of his examined such topics as church-state relations (Ryan 1979), Irish families (Ryan 1965, 1994), and religion (Ryan 1983).

\section{Explaining the Irish Catholic Sociology Story}

This paper began by asking why Catholic sociology in Ireland suddenly went into decline in the 1950s. There are organisational and intellectual factors located at a national and international level that help explain this change. First, Irish Catholic sociology clerics in the 1930s and 1940s worked in a largely self-contained church environment - apart from their reading of papal encyclicals coming from Continental Europe and religious sociology from other contexts - this meant that they were insulated from disciplinary norms and practices circulating in other contexts where secular sociology operated as a rival disciplinary model. As a result of cross-cutting Catholic sociology (Furfey 1946; Waldron 1950)—involving visits by Catholic action personnel to other Catholic countries and the reading of confessional literature originating in different parallel settings - in the disparate contexts of France, Germany, the U.S., and Ireland, it took on similar patterns - as mentioned earlier, these included the use of study circles, the publication of periodicals, and the 
development of a co-operative movement. Because of Catholic theology's then suspicion of secular social science disciplines, Catholic sociology was also ghettoised from norms operating in other social science disciplines within Ireland.

By the 1950s, however, Irish Catholic sociologists played an increasingly important part in international research networks that brought them into contact with the norms and practices operating in the wider discipline. This meant that they came under stronger normative pressures than before to bring Catholic sociology into dialogue and contact with mainstream sociology and its norms around empirical fact gathering, hypothesis testing, value neutrality, and so forth. Irish sociologists who received their training in the 1960s and 1970s frequently did so in UK and US universities (Jackson 1987) with the result that they were increasingly exposed to the mainstream discipline's orientations and dispositions. When they returned to take up jobs in Irish universities, they brought this secular, empirical training to their work. Within this graduate training, there was little in Catholic sociology that was recognisably sociological.

Further normative pressure was exerted on Irish Catholic sociology as a result of Vatican II. This council's emphasis on coming to terms with the modern world meant that it was no longer normative to ghettoise theology from sociology or from confronting theological reflections with real-world empirical data. This shift from a missionary to a pastoral christianisation strategy (Vallier 1970) meant that remaining isolated from the mainstream discipline became increasingly difficult to sustain.

Around the 1950s changes were also occurring in the national higher education environment and in particular increased competition from secular third level institutions (Corish 1995). As a result the church came under pressure to exert its influence over the laity in a way that did not involve establishing and promoting confessional programmes and instead focused on generating commitment and loyalty to the church via a more general approach to education (while at the same time preserving its Catholic coloration) and social provision generally. Taken together, involvement with secular sociology, shifts in the church's Christianisation policies, and changes in the national educational context, help account for the trajectory of Irish Catholic sociology.

Two important differences set Irish Catholic sociology apart from its counterpart in the U.S. context. First, Catholic sociology in Ireland was not established as a counterpoint to existing secular sociological organisations and it lacked a rival disciplinary organisation with which it competed for members (Brewer 2007; Varacalli 1990). From the early 1900s to the 1940s, Catholic sociology was the only rubric under which sociology was practised in Ireland. By contrast, in the U.S., Catholic sociological organisations developed alongside non-confessional equivalents and each viewed the other with some hostility (Kivisto 1989). This meant that Irish Catholic sociologists' engagement with secular sociology was through their reading of the international literature and linkages with secular sociologists in other contexts. In the Irish context, the transition to a secular discipline and away from a confessional model was a conflict-free transition and had little of the fraught and politicised history it had in Western Europe (Dobbelaere 1989) and America. U.S. Catholic sociologists tended to be more strident and defensive because they faced a rival secular agenda from the mainstream of the discipline. At the same time, U.S. Catholic sociology was ideologically compatible with the "Social Gospel" promoted 
by Protestant clerics. Secondly, the Irish experience differs from the U.S. case in respect of the broader influence of religion on sociology - the Protestant religious tradition shaped sociology in the U.S.- though its influence may be overstated (Swatos 1989) - in a way that it did not in Ireland. This cacophony of religious influences in the U.S. meant that sociology there was more fragmented, variegated and politicised.

\section{Conclusion}

This paper has sought to shed light on the institutional and intellectual influences of the Catholic Church on sociology in Ireland while at the same time placing this specifically Irish experience of Catholic sociology in a wider international perspective. Irish Catholic sociology bore interesting similarities with Catholic sociology in France, Germany and the U.S. - in terms of the kinds of topics they discussed and the resources they drew upon to promote their work-but also striking differences - in terms of its theoretical depth and originality (compared to German Catholic sociology) and methodological rigor and sophistication (compared to French Catholic sociology). To some extent, Irish Catholic sociologists were embedded in this international network of Catholic sociology but intellectually their work was more derivative than in the other national cases. Of the four countries considered here, French and German Catholic sociologists were generally better catered for in terms of a publishing architecture of Catholic periodicals and the like than Irish and U.S. Catholic sociologists.

For the most part, though, this paper focused on Catholic sociology in Ireland. In particular, three important phases in the story about the origins and development of Irish Catholic sociology were discerned. In its earliest phase, it was confessional in orientation and for this reason tended to be reluctant to engage in scientific or empirical studies of everyday social life, preferring instead to take the papal encyclicals as its guide to Irish social life - thereby reflecting its preference for the deductive method. Peter McKevitt embodied the first phase in Irish Catholic sociology. This normative, deductive, and philosophical version of sociology looked very different to sociology as we know it today. Although McKevitt did not reject the use of empirical approaches to the study of society, he was not a champion of it in his own work. He sought to theologise sociology and to sociologise theology. Along with a handful of other clerics, he built up a modest literature on Catholic sociology comprising a few books, journal articles, and other short pieces. During his academic career, sociology in Maynooth was literally a one-man enterprise and it was mainly inward-oriented and suspicious of engagement with anything other than Catholic theology and ethics.

The second phase of Irish Catholic sociology involved bringing theology into dialogue with mainstream sociology and Jeremiah Newman represented this phase well. He reflected continuity with his predecessor by emphasising the need to promote Catholic sociology but, more than McKevitt, sought to utilise the standard sociological methods of social surveys in gathering data to confront the idealistic claims of Catholic theology.

In common with the trajectory of sociology in other national contexts, sociology in Ireland moved from being a largely confessional, denominational discipline in the 1930 s through to the 1950 s, to a more secular and 'disenchanted' discipline from the 
1960s on. Over this timeframe, the relationship of religious ethics to the empirical world within Irish Catholic sociology shifted from one of isolation to abrasion to detachment. Changes in the Catholic church, in higher education environments, and in the wider discipline played out in this "career" of Irish Catholic sociology and its turn toward secular mainstream sociology.

But the emergence of modern secular Irish sociology and the jettisoning of its Catholic coloration did not represent a complete break with earlier Irish Catholic sociology. Significantly, secular sociologists in the 1960s and 1970s appropriated Catholic sociology's emphasis on public engagement and its disciplinary strengths in rural life, family, education and religion. ${ }^{15}$

As an institutional entity with a professional organisation, periodical and books, Irish Catholic sociology, then, ceased to operate in the early 1960s. Its sudden organisational demise occurred alongside the collapse of the publication machinery of periodicals and magazines that maintained it during its heyday. As an intellectual project emphasising the applied nature of sociology, Catholic sociology did not completely disappear and reverberates today in still resonant emphases on making sociology engaged and socially relevant (Burawoy 2001).

While this paper has attempted to examine the historical origins and development of Catholic sociology in one particular case, Ireland, and to place this in a wider international context, there is scope to enlarge the comparative dimension even more by extending the analysis to include other Western European Catholic countries such as Austria, Belgium, Italy, Portugal, and Spain. More research is also called for in terms of investigating the cross-currents between different national Catholic sociologies and their interaction with Rome as well as how the specific university governance structures and histories of different European societies shaped the direction Catholic sociology took.

Acknowledgments I am very grateful to the editor and the anonymous reviewers for their thoughtful comments and suggestions on an earlier version of this article.

\section{References}

Barnes, S. H. (1961). Quebec catholicism and social change. The Review of Politics, 23(1), 52-76.

Baum, G. (1989). Sociology and salvation: do we need a catholic sociology? Theological Studies, 50, $718-743$.

Beckford, J. A. (1990). The sociology of religion 1945-1989. Social Compass, 37(1), 45-64.

Beveridge, W. H. (1942). Social insurance and allied services. London: Her Majesty's Stationary Office.

Blasi, A. J., \& Donahoe, B. F. (2002). A history of sociological research and teaching at Catholic Notre Dame University, Indiana. Lewiston: The Edwin Mellen Press.

Bolster, E. (1979). The Knights of Columbanus. Dublin: Gill and Macmillan.

Boulard, F. (1960). An introduction to religious sociology. London: Darton, Longman and Todd.

Brewer, J. (2007). Sociology and theology reconsidered: religious sociology and the sociology of religion in Britain. History of the Human Sciences, 20(2), 7-28.

Burawoy, M. (2001). Berkeley sociology: Past, present and future. Retrieved June 8, 2010 (http://burawoy. berkeley.edu/PS/Berkeley\%20Sociology.pdf).

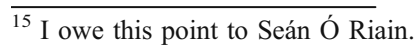


Cahill, E. (1932). The framework of a christian state: An introduction to social science. Dublin: M.H. Gill \& Son, Ltd.

Canning, B. (1987). Bishops of Ireland 1870-1987. Ballyshannon: Donegal Democrat.

Cavendish, J. C. (2007). The sociological study of American Catholicism: Past, present and future. In A. J. Blasi (Ed.), American sociology of religion: Histories (pp. 151-176). Leiden: Brill.

Christus Rex. (1970). Monsignor Jeremiah Newman. XXIV, 3.

Conway, B. (forthcoming). A history of sociology at St. Patrick's College, Maynooth and the National University of Ireland, Maynooth. Sociological Origins.

Corish, P. (1970). A history of Irish Catholicism: The church since Emancipation. Dublin: Gill and Macmillan.

Corish, P. J. (1995). Maynooth College 1795-1995. Dublin: Gill and Macmillan.

Cork University Record. (1949). No. 17.

Cronin, M. (1927). Primer of the principles of social science. Dublin: M.H. Gill \& Son Ltd.

Curtis, M. (2010). A challenge to democracy: Militant catholicism in modern Ireland. Dublin: The History Press Ireland.

Daly, C. B. (1967). Christus Rex: The first twenty-five years. Belfast: P. Quinn \& Co.

Daly, M. (1999). The functioning family: catholicism and social policy in Germany and Ireland. Comparative Social Research, 18, 105-133.

Delacroix, S. (1952). Parish inquiries in France. American Catholic Sociological Review, 13(3), $169-173$.

Dillon, M. (1993). Debating divorce: Moral conflict in Ireland. Lexington: University of Kentucky Press.

Dobbelaere, K. (1989). CISR, An alternative approach to sociology of religion in Europe: ACSS and CISR compared. Journal for the Scientific Study of Religion, 50(4), 377-389.

Dobbelaere, K. (2000). From religious sociology to sociology of religion: toward globalization? Journal for the Scientific Study of Religion, 39(4), 433-447.

Ederer, R. J. (1998). My journey into solidarism. Catholic Social Science Review, 3, 79-88.

Facey, P. (1964). “Aggiornamento”. Sociological Analysis, 25(3), 137-140.

Fahey, T. (1998). The catholic church and social policy. In S. Healy \& B. Reynolds (Eds.), Social policy in Ireland: Principles practice and problems (pp. 411-429). Dublin: Oak Tree Press.

Fichter, J. H. (1966). Send us a boy-get back a man. Washington: Jesuit Education Association.

Fichter, J. H. (1973). One-man research: Reminiscences of a Catholic sociologist. New York: Wiley.

Fr. Patrick Purcell. (1964). Rural Sociology, 60.

Fuller, L. (2002). Irish Catholicism since 1950: The undoing of a culture. Dublin: Gill and Macmillan.

Furfey, P. H. (1946). Foreign publications. The American Catholic Sociological Review, 7(4), 277-279.

Gauvreau, M. (2005). The catholic origins of Quebec's quiet revolution, 1931-1970. Montreal and Kingston: McGill-Queen's University Press.

Gill, R. (1974). The critique of religious sociology. Social Studies, 3(2), 103-117.

Hartigan, M. (1992). The Catholic laity of Dublin, 1920-1940. Ph.D. dissertation, Department of History, St. Patrick's College, Maynooth, Ireland.

Hervieu-Léger, D. (1990). Religion and modernity in the French context: for a new approach to secularization. Sociological Analysis, 51, S15-S25.

Hill, M. R. (1999a). A symposium on Frédéric Le Play and Amos G. Warner: Le Play, Warner and the sociology of fieldwork. Sociological origins, 1(2), 66-68.

Hill, M. R. (1999b). Bio-bibliography: Eva J. Ross (1903-1969): Catholic Sociologist. Sociological origins, 1(2), 106-110.

Inglis, T. (1998). Moral monopoly: The rise and fall of the catholic church in modern Ireland (2nd ed.). Dublin: UCD Press.

Irish Catholic Directory and Almanac. (1939). Dublin: John Mullaney.

Irish Catholic Directory and Almanac. (1945). Dublin: John Mullaney.

Irish Catholic Directory and Almanac. (1947). Dublin: John Mullaney.

Irish Catholic Directory and Almanac. (1950). Dublin: John Mullaney.

Irish Catholic Directory and Almanac. (1951). Dublin: John Mullaney.

Irish Catholic Directory. (1975). Dublin: Veritas.

Jackson, R. M. (1959). An account of religious sociology in France. The Sociological Review, 7(2), $197-212$.

Jackson, J. (1987). Social science in Ireland. International Social Science Journal, XXXIX(112), $273-281$.

Kelly, A. (1999). Catholic action and the development of the Irish welfare state in the 1930s and 1940s. Archivium Hibernicum, LIII, 107-117.

Keogh, D. (1995). Ireland and the Vatican: The politics and diplomacy of church-state relations 19221960. Cork: Cork University Press. 
Keogh, D. (1996). The role of the Catholic Church in the Republic of Ireland 1922-1995. In Building trust in Ireland: Studies commissioned by the forum for peace and reconciliation (pp. 89-204). Belfast: The Blackstaff Press.

Kivisto, P. (1989). The brief career of catholic sociology. Sociological Analysis, 50(4), 351-361.

Lane, R. (1954). The use of empirical research in sociology. Christus Rex, 7, 234-241.

L'Estrange, S. (2007). Religious authority, religious rule: the priesthood, politics and the promotion of the "Reign of Christ" in mid-twentieth century Ireland. European Journal of Sociology, XLVIII(2), 239-261.

Marjolin, R. (1937). French sociology-Comte and Durkheim. The American Journal of Sociology, 42(5), 693-704.

Maynooth College Calendar. (1937). Dublin: Brown and Nolan.

McCaffery, B. J. (1956). Review of Co-Responsibility in Industry, by Jeremiah Newman. Christus Rex, X, 295-299.

McGarry, J. (1958). Review of What is Catholic Action? by Jeremiah Newman. The Furrow, 9(9), 619-620.

McKevitt, P. (1935). The Jews in Christendom. Irish Ecclesiastical Record, 46, 348-362.

McKevitt, P. (1938). R.S. Pringle-Pattison 1856-1931 and the philosophy of naturalism, Ph.D. dissertation, Institut Supérieur de Philosophie, Catholic University of Leuven, Belgium.

McKevitt, P. (1940). The spending of the living wage. Irish Ecclesiastical Record, LVI, 143-155.

McKevitt, P. (1941). James Connolly and the Irish labour movement. Irish Ecclesiastical Record, LVII, 128-138.

McKevitt, P. (1943). The Beveridge plan reviewed. Irish ecclesiastical record, LXI, 145-150.

McKevitt, P. (1944). The plan of society. Dublin: Catholic Truth Society.

McKevitt, P. (1947). The study circle. Christus Rex, 1(1), 34-39.

McKevitt, P. (1952a). Sociological aspect of rural decline. Christus Rex, 6, 52-62.

McKeviitt, P. (1952b). Book notes. Christus Rex, 6, 468-471.

McKevitt, P. (1955a). An instrument of priests' social action: Christus Rex. Christus Rex, IX, $259-265$.

McKevitt, P. (1955b). Leisure. Rural Ireland. 35-40.

McKevitt, P. (1955c). The background of Rerum Novarum. Christus Rex, 336-345.

McKevitt, P. (1956a). Christianity and cooperation. Rural Ireland, 17-23.

McKevitt, P. (1956b). "Comments." Christus Rex X: 40-45 (feature article in which Peter McKevitt and Professors C.B. Boyle, E.J. Conway, and T. Dillon, J.J. Byrne, P. Moran comment on the Farmers' Commission report on the proposed Agricultural Institute).

McKevitt, P. (1962). Sermons for sundays. Irish Ecclesiastical Record, 97, 313-318.

McKevitt, P. (1965). Evolving communism. Irish Ecclesiastical Record, CIV, 193-201.

McKevitt, P. (1967). Review of Reminiscences of a Maynooth Professor, by Walter McDonald. The Furrow, 18(10), 608-610.

McKevitt, P. (1970). Epilogue: Modern Ireland. In P. Corish (Ed.), A history of Irish catholicism: The church since emancipation, vol. 10 (pp. 1-29). Dublin: Gill and Macmillan.

Meehan, D. M. (1982). Maynooth again remembered. Kerry: The Kerryman Ltd.

Mueller, F. H. (1946). Review of the plan of society, by Reverend Peter McKevitt. American Catholic Sociological Review, 7(2), 144-145.

Mullan, D. (1960). Christus Rex Congress 1960. The Furrow, 11(6), 403-407.

Murray, P. \& Feeney, M. (2010). Muintir na Tíre seeks funding for rural sociology in 1960s Ireland. National Institute for Regional and Spatial Analysis (NIRSA) Working Paper No. 63, National University of Ireland, Maynooth. Retrieved 31 December, 2010 (http://www.nuim.ie/nirsa/research/ working papers.shtml).

Newman, J. (1951). Recent philosophical trends on the continent. Irish Ecclesiastical Record, LXXVI, 14-25.

Newman, J. (1953). The sociology of religion. Christus Rex, VII, 583-590.

Newman, J. (1954). Foundations of justice: A historico-critical study in Thomism. Cork: Cork University Press.

Newman, J. (1955). Co-responsibility in industry: Social justice in labour-management relations. Dublin: M.H. Gill.

Newman, J. (1957). The sociology of rural Ireland. Rural Ireland, 75-80.

Newman, J. (1958a). Priestly vocations in Ireland. The Furrow, 9(11), 710-721.

Newman, J. (1958b). What is catholic action? An introduction to the lay apostolate. Dublin: M.H. Gill and Son Ltd.

Newman, J. (1958c). The future of rural Ireland. Studies, XLVII, 402.

Newman, J. (1958d). Vocational organisation and the co-operative movement. Christus Rex, 12, 171-184.

Newman, J. (1959). Review of vocation de la Sociologie Religieuse: Sociologie des Vocations, by Paroisses Urbaines: Paroisses Rurales. The Furrow, 10(6), 416-417.

Newman, J. (1962). The priests of Ireland: a socio-religious survey. Irish Ecclesiastical Record, 98, 1-27.

Newman, J. (Ed.). (1964). The Limerick rural survey. Tipperary: Muintir na Tíre. 
Newman, J. (1965). Change and the catholic church: An essay in sociological ecclesiology. Baltimore: Helicon Press.

Newman, J. (1966). Vocations in Ireland - 1966. Christus Rex, XX, 105-135.

Newman, J. (1967). Changing functions of the rural community. Christus Rex, XXI(1), 60-69.

Newman, J. (1968). Vocations to the sisterhood in Ireland. Christus Rex, XXII, 7-16.

Newman, J. (1972). Introduction to sociology. Dublin: Talbot Press.

Nuesse, C. J. (1998). Catholic sociology: memoir of a mid-century controversy. U.S. Catholic Historian, 16(3), 94-110.

O’Brien, D. J. (1971). The American priest and social action. In J. T. Ellis (Ed.), The Catholic Priest in the United States: Historical Investigations (pp. 423-469). Collegeville: St. John's University Press.

O'Driscoll, F. (1994). The search for the christian state: An analysis of Irish social catholicism, 1913-1939. M.A. thesis, University College Cork.

O'Leary, D. (2000). Vocationalism and social catholicism in Twentieth-Century Ireland. Dublin: Irish Academic Press.

Peillon, M. (1982). Contemporary Irish society: An introduction. Dublin: Gill \& Macmillan.

Périer, P. (2002). Le Play and his followers: over a century of achievement. International Social Science Journal, 50(157), 343-348.

Poggi, G. (1967). Catholic action in Italy: The sociology of a sponsored organization. Stanford: Stanford University Press.

Rawe, J. C. (1940). Review of Belgian Rural Cooperation by Eva J. Ross. The American Catholic Sociological Review, 1(3), 158-160.

Reed, M. S. (1981). An alliance for progress: the early years of the sociology of religion in the United States. Sociological Analysis, 42(1), 27-46.

Reed, M. S. (1982). After the alliance: the sociology of religion in the United States from 1925 to 1949. Sociological Analysis, 43(3), 189-204.

Research and Development Unit. (1971). A Survey of Catholic Clergy and Religious in Ireland, 1971. Dublin: Catholic Communications Institute of Ireland.

Ryan, L. (1967). Social dynamite: A study of early school-leavers. Cork: University College Cork.

Ryan, W. (1973). Assimilation of Irish immigrants in Britain. Ph.D. dissertation, Department of Sociology, Saint Louis University, Saint Louis, MO.

Ryan, L. (1965). Sociologists look at the Irish family. Rural Ireland, 77-83.

Ryan, L. (1983). Faith under survey. The Furrow, 34(1), 3-15.

Ryan, L. (1994). The changing Irish family. The Furrow, 45(4), 212-220.

Ryan, L. (1979). Church and politics: the last twenty-five years. The Furrow, 30(1), 3-18.

Ryan, L. (nd). The changing direction of Irish seminaries: A survey report. Dublin: Research and Development Unit, Catholic Communications Institute of Ireland.

Ross, E. J. (1940). Sociology and the catholic. American Catholic Sociological Review, 1(1), 6-9.

Ross, E. J. (1950). The sociology of religion in France today. American Catholic Sociological Review, 11 (1), 3-14.

Sharkey, S. R. (2005). Framing a catholic sociology for today's college students: historical lessons and questions from Furfey, Ross, and Murray Part II. Catholic Social Science Review, 10, 235-270.

Sullins, P. (nd). Sociology: A catholic critique. Retrieved October 20, 2010 (http://faculty.cua.edu/sullins/ published\%20articles/soccath.pdf).

Swatos, W. H. (1989). Religious sociology and the sociology of religion in American at the turn of the twentieth century: divergences from a common theme. Sociological Analysis, 50(4), 363-375.

Swatos, W. H. (1998). Encyclopedia of religion and society. Walnut Creek: Altamira Press.

Varacalli, J. A. (1990). Catholic sociology in America: a comment on the Fiftieth Anniversary issue of Sociological Analysis. International Journal of Politics, Culture and Society, 4(2), 249-262.

Vallier, I. (1970). Catholicism, social control, and modernization in Latin America. Englewood Cliffs: Prentice-Hall.

Vogt, E. D. (1955). Religious sociology and the standardization of its methods. Rome: Pont. Universitas De Propaganda Fide.

Waldron, J. (1950). An Rioghacht (The League of the Kinship of Christ): a retrospect. The Irish Monthly, 78(924), 274-280.

Ward, C. K. (1960). Review of Limerick Rural Survey: Interim Report: Migration, by Patrick McNabb. Studies, XLIX, 437.

Ward, C. K. (1964). Socio-religious research in Ireland. Social Compass, 11(3), 25-29.

Waters, W. R. (1988). Franz Mueller, Eminent social economist. Forum for Social Economics, 17(2), 51-52.

Whyte, J. H. (1984). Church and state in modern Ireland 1923-1979. Dublin: Gill and Macmillan. 